\title{
Influence of Working Capital Supervision on the Performance of firm Listed on the Nigerian Stock Exchange
}

\author{
Michael Linus Ogbada", Yusuf Jeremiah Karfe, Gambo Sule, Muhammad Barkindo Umar \\ Department of Accounting and Finance, Faculty of Management Science, Abubakar Tafawa Balewa University, Bauchi, Bauchi State, Nigeria
}

DOI: $10.36348 /$ SB.2019.v05i12.002

| Received: 20.11.2019 | Accepted: 27.11.2019 | Published: 17.12.2019

*Corresponding author: Michael Linus Ogbada

\section{Abstract}

The global economy world has changed rapidly due to the rise of economic and technological variations featured by the incremental global competition which has made the directors of firms more accountable in carrying out their operations. Financial Decision making is one of the significant roles played by the organization management. Making decisions sheds lights on the whole financial affairs. This is not exceptional in working capital Decisions. Designing and developing working capital supervision influence the improvement of the firms operations. This study intends to find empirical evidence about the influence of working capital supervision on the performance of the firm. The performance evaluation measures include distinguished economic value added and market value added. In doing so, a sample composed of the firms listed on the Nigerian Stock Exchange for a five year period including 2013 to 2018 has to be considered. The regression results will be present that there is no significant relationship between working capital supervision and supervised economic value added. However, the variables of working capital supervision and market value added are significantly associated. As a whole, the managers might enhance the firm's financial performance through declining the liquidity cycle.

Keywords: Working Capital Supervision, Distinguished Economic Value Added, Market Value Added, Nigerian Stock Exchange.

Copyright @ 2019: This is an open-access article distributed under the terms of the Creative Commons Attribution license which permits unrestricted use, distribution, and reproduction in any medium for non-commercial use (NonCommercial, or CC-BY-NC) provided the original author and source are credited.

\section{CHAPTER ONE}

\section{Background of the Study}

\section{INTRODUCTION}

Working capital refers to the firm's investment in short -term assets such as cash, account receivables, short-term or marketable securities and inventories [1]. Capital is the fundamental means of financial supervision so that it might be declared that the whole business operations require investments. Capital includes the financial resources utilized by the firms. In doing so, financial supervision identifies the framework of the relationship between the capital and the firm. Based on the importance of the capital in organizational processes, its supervision has been highly considered.

Working capital supervision, however, holds a great share of the organizational capital and specifically in small firms. Working capital supervision based on the elements of the supply chain is therefore important. There is a close direct relationship between the sales growth and finance of the current assets. Increasing sales usually leads to increasing investments in the inventories, accounts receivables and cash. All these requirements should be financed. The variations in these elements are so quick and that is why the financial manager should be coconscious about the changes [2]. Working capital director of an organization should select proper strategies in terms of different situations in order to handle the current assets and liabilities more effectively and contribute to economical financing. By doing so, the return of the firm is improved and the wealth of the shareholders is maximized [3].

Shareholders, however, always look for those ways by which they could evaluate the performance of the managers in terms of generating wealth for the firms. Practically, it is shown that the improper information and measures are interpreted in the judgments of the managers. Lack of the proper measures for performance evaluation and value conception lead the stock prices not to get close to their real values. This phenomenon typically discomposes 
the balance and causes some firms to benefit from excess profits while the other one loses huge amounts. On the other hand, lack of compensation of the directors for their performance in maximizing the shareholders' wealth creates a gap between the interests of the managers and shareholders. This is the primary means of the conflict of interests among the agencies and the owners. Therefore, this current paper studies the influence of level of working capital supervision on the firm's performance by using the measures of distinguished economic value added and market value added.

In other words, this study seeks to find an answer to a question concerning whether working capital supervision influences the performance of the firms listed in the Nigerian stock exchange? The next section will reviews the prior literature and the theoretical bases which are subsequently provided. The appropriate methodology will be recognized in section four and will be followed by the findings in the next section. Lastly, the conclusion and discussions will be provided.

\section{CHAPTER TWO \\ LITERATURE REVIEW \\ Research Background}

In this section, the prior studies conducted in other foreign countries are provided. Enayati [4] investigated the current position of the working capital of the selected firms during 2008 to 2012. The findings of this study revealed that there is a significant association between the cash management methods and the methods of managing receivables with the firm's liquidity. Khorram Nezhad [5] segregated the financial and operational policies of the firms and analyzed the working capital management of the medical firms listed on the Tehran Stock Exchange. He concluded that the financial policies of the medical firms are generally aggressive while their operational policies are conservative. Moreover, Rahnema Roud Poshti and Kiyayi [6] conducted a study titled "examining the impact of working capital management strategies on the firms listed on the Tehran Stock Exchange". They collected the six year data of the selected firms operating in two categories of chemical and food industries. They found that the working capital management strategies and liquidity and solvency are significantly associated. Izadi Niya and Taaki [7] selected a sample composed of the big and small Iranian firms to find empirical evidences about the impact of working capital management on the profitability. The regression results indicated that the cash conversion cycle and return on asset are significantly and inversely related. Additionally, they showed that investment of huge amounts in inventories and accounts receivables decreases the profits. Yaghoub Nezhad et al. [8] tested the relationship between the working capital management and profitability of the
Tehran listed firms. Their findings implied that the variables of the working capital management and profitability are inversely associated. Reza Zadeh and Heydarian [9] explored the effect of working capital management on the profitability of the firms listed on the Tehran Stock Exchange. They concluded that the managers can decrease the inventory level and the average collection period for creating wealth for the firm. Fathi and Tavakkoli [10] studied about the relationship between the working capital management and financial performance of the economic entities. They interpreted that deferring the average collection period, inventory turnover and average payment period are significantly related. They also concluded that shorter cash conversion cycle and firm's profitability are associated. Assar Zadeh [11] examined the elements of working capital management and their relationship with the three measures of performance including economic value added, return on assets and Tobin's Q ratio. He documented that the working capital management and economic value added are significantly linked to each other; however, there was no significant relationship observed between return on assets and Tobin's Q and working capital management.

Anand and Pracash Guptha [12] considered the performance of the firms over the years from 1991 to 2001 in terms of their performance in working capital management. The results showed that the selected measures for performance evaluation of working capital management are useful in evaluating the performance of the working capital and they contribute to analyzing the risk and return of the firms. Howorth and Westhead [3] studied the position of working capital management of small firms. They indicated that those firms using less working capital have lower growth rates, less external financial resources, less credit purchases, shorter manufacturing cycles and less cash sales. Negarbo [14] selected 250 firms as the sample to test the working capital management in them. The conclusions showed that predicting cash flows and growth rate of the firms are the major indicators of working capital supervision. They also found that changing the size and compound of the assets are not significantly affected by the cash flows prediction and sales growth. They are highly influenced by some factors such as the business nature of the firms, sales, firm size and profitability. The impact of working capital management on the value of 150 firms during 1990 to 2004 was examined by Laplent [15]. It was found that the trends of the firms, size and future sales growth affect the efficiency of the working capital management. Padachi [16] considered the relationship between the working capital management and performance of the small Mauritian firms for a six year period covering 1998 to 2003. The positive relationship between working capital management and firms' performance was confirmed by the authors. Samiloglue and Demirnes [17] tried to find whether the profitability 
and working capital management of a sample of Turkish listed firms are related. Their study involved 1998 to 2007 and they documented that average collection period, inventory turnover, leverage and profitability are in significant inverse relationships. However, it was found that growth and profitability are directly associated. Gill et al. [18] showed that the cash conversion cycle and profitability are related and this is identified through gross operational earnings. Their study concerned the working capital management and the profitability of the American firms. Raheman et al. [3] selected some firms in Pakistan during 1998 to 2007 in order to seek the impact of working capital management on the organizational performance. They argued that cash conversion cycle and inventory turnover significantly affect the operations of the firms.

Enqvist et al. [9] documented that there is a negative relationship between cash conversion cycle and profitability. Nobanee and AlHajjar [19] found that the managers might increase the profitability and operating cash flows through shortening the cash conversion cycle and average collection period.

\section{Theoretical Background}

Working capital is sometimes substituted by capital circulate because it includes a portion of the firm's capital which is an essential element. Working capital is defined as the investment of the firm in the current or short-term assets such as cash, short-term securities, accounts receivable and inventories [1]. Working capital supervision refers to the whole aspects of managing the current assets of the firms. Working capital requires handling different current assets and liabilities and is also composed of decisions related to the finance of the current assets through current debts or equity. Significance of the capital in the organizational processes made its management having essential importance. In general, working capital holds a large proportion of the capital in all organizations and specially the small ones. Managing capital based on the mechanisms of managing the elements of supply chains are also very important [10]. Financial affairs of the firms might be classified into three main sections of capital budgeting, capital structure and working capital management. Managing long-term capital is related to capital budgeting and capital structure; while management of the current assets and liabilities deals with the working capital management [20]. Working capital of a firm is defined as the amounts invested in the current assets of the organization. Skilling [21] believes that working capital represents the investments in the cur-rent assets and liabilities, cash, short-term securities, accounts receivable and inventories. Form his point of view; working capital is determining the volume and compound of the resources so that the shareholders' wealth is maximized. The policies of the working capital include those principles and plans dealing with the tasks of current assets and liabilities.
Many authors and scholars referred to three types of working capital: aggressive, mediator and conservative. The major difference between these policies is the level of net working capital supervision which is equal to the difference between current assets and liabilities [10].

Many specific factors affect working capital supervision. Obviously, the elements at different levels have changed the need to a proper working capital. Nature of the manufacturing (firms' operations) process, manufacturing period of the firm and its policy, credit guideline of the suppliers, growth and development affairs, facility in attaining the material, profit level and tax rate are among those factors affecting the level of working capital. Attitudes of the managers toward risk determine the level and compound of the working capital. Conservative managers tend to select the volume and compounds by which the risk is mitigated. However, some other managers intend to select the volume and compound of the working capital supervision which increases the return. Four strategies (independent variables) used in this study for identifying the working capital are introduced.

\section{Average Collection Period}

This variable is defined as the number of the days which is needed to collect the receivables. In other words, it is the average period for which receivables are outstanding. The information about the net annual sales of the firm and the average beginning and ending receivables are used [2]:

Average Collection Period $=$ (Average Accounts Receivable×365)/(Net Sales) (1)

\section{Average Payment Period}

This is the number of days a company takes to pay off the accounts payable. The average beginning and ending accounts payable are used to measure the average payment period [3]:

Average Payment Period $=$ (Average Accounts Payable×365)/(Purchases) (2)

\section{Inventory Turnover in Days}

Inventory turnover is the period of time taken to sell the inventories. Average inventories at the beginning and ending of the period are used to calculate this variable. Inventory Turnover in Days $=$ (Average Inventory $\times 365) /($ Cost of Goods Sold) (3)

\section{Cash Conversion Cycle}

Cash conversion cycle is the time taken to convert the purchased material to the finished goods and receive the cash from the sales. 
Cash conversion cycle $=($ Average Collection Period + Inventory Turnover) - Average Payment Period [2]. (4)

\section{Theoretical Bases and Concepts of Financial Performance}

Investors always take performance evaluation of the firms into account for the purpose of identifying the desirable investment opportunities. The satisfactory performance of the industry is the factor which motivates the shareholders to invest their funds in a specific operation which would finally increase the firm value and shareholders' wealth. Optimum operation of a firm is handled by the managers and this ensures that giving the required incentives to the managers leads them to make the optimum decisions. Finally, it should be noted that by selecting the proper performance evaluation measures which are the bases for compensating the directors, the shareholders will make better decisions and align the interests of directors with themselves. This will finally accelerate the achievement to the goals. Today, performance measurement is one of the essential topics which have been much debated. Different performance evaluation methods might response to some questions concerning the degree to which the firms are trying to maximize the interests of the shareholders and also the indexes which are taken into account by the banks and financial institutes to grant facilities to the firms. Other issues also involve the dimensions which are regarded by the managers and the legal points considered by the governmental agencies. Performance evaluation is a necessity and accepted measures should be applied to consider the different aspects in terms of the limitations in the operations and utilization of the facilities [6]. The ultimate goal of establishing any economic entity is maximizing the intrinsic value for the shareholders during consecutive periods (value creation). Therefore, organizational strategies, resources and the performance evaluation systems should be completely concentrated on achieving this goal. The existence, implementation and development of the strategies of creating relative advantage and persistent value creation significantly impact the firm value and stock price. Capital market should attain the instruments and leverages of performance measurement for making sure that the management is capable of developing the mentioned strategies.

In this study, two measures of distinguished economic value added and market value added (dependent variables) are used. These measures are selected among the other well-known measures in economic trends of performance evaluation considered by the managers, financial advisors, investors and researchers.

\section{Distinguished Economic Value Added}

Distinguished economic value added (DEVA) is an analytic framework for evaluating the operational performance and the amount of the created value for the shareholders. DEVA is the same as the economic value added (EVA); however, the difference is that the capital expenditures are computed by the market value of the firms' assets rather than the book value of the assets. EVA is a measure which facilitates the value creation for the shareholders, but DEVA is an instrument for evaluating the prior financial performance of the firms. Generally, DEVA is used to measure the external performance. Comparing DEVA and EVA, it can be concluded that the changes in the market value lead to changes in the capital expenditures which are not the same as the changes in the net operation profit after tax [18].

The following equation is used to calculate DEVA

(Heydar Pour and Mostofi [22].

DEVA = NOPAT - WACC (Mcapitalt-1) (5)

Where in it;

NOPAT: Net operating profit after tax at the end of period $\mathrm{t}$,

WACC: Weighted average of cost of capital,

(Mcapitalt-1): Market value of the firms at the beginning of period $t$ and end of period $t-1$.

3.2.2. Market Value Added

Stewart [23] introduced another measure known as market value added for those firms which create value. If the total market value of the firm is more than the invested amount, then this firm is managed so that creates wealth for the shareholders. Once the market value of a firm is lower than the invested resources, the operations of the firm cause the shareholders' wealth to be lost. Market value added is caused by EVA because it is the result of the present value of the future economic values. Regardless of the fact that EVA is an internal measure for performance evaluation, this measure finally develops an external measure titled market value added. This measure shows the evaluation of the investors from the performance of the firms. Therefore, EVA is an internal measure of performance evaluation and market value added is the external measure for evaluating the performance [14]. This measure is computed by the difference between the market value and book value of the owners' equity [24].

\section{CHAPTER THREE RESEARCH METHODOLOGY Introduction}

This study is conducted based on the real data and is classified as a semi empirical study. The findings of this study will be useful for the users of the financial statements. That is why this is an applied study. Additionally, this paper is a descriptive study in terms 
of analyzing the collected information by describing the relationship between the variables. The influence of working capital supervision on the performance of the listed firms on the Nigerian Stock Exchange has been examined in this study. Consequently, the theoretical frameworks of the study are being studied to achieve the research objectives. The required data is collected by different methods including literature review for the theoretic discussions. The needed data for the research variables has been gathered by software verified by Nigerian Stock Exchange and the financial statements publicly issued. The collected data has been analyzed by EXCEL and SPSS software.

\section{Population and Sample}

The population of this study composed the whole listed firms on the Nigerian Stock Exchange. This population has been selected since the financial statements of these firms are publicly available and the content information is homogenous which facilitate data analysis. Filtering technique has been applied to select a proper sample for data analyses. Those firms which are qualified in terms of the following characteristics have been selected. These specifications are:

- The firms are listed on the Nigerian Stock Exchange from the beginning of 2013 and their stocks are traded until the end of 2018.

- This study considers the non-financial firms. Consequently, banks and all other investment institutions have been excluded from the sample.

- The end of the fiscal years should be consistent with the calendar year. Accordingly, those firms which have inconsistent ending of the fiscal year have been excluded.

- The detailed data about the annual financial statements and the stock prices at the end of the year should be available.

\section{Hypotheses Development}

Based on the relationship between the research variables, two main hypotheses are developed and four subsidiary hypotheses are also provided for each main hypothesis:

The first main hypothesis (H1): There is a significant relationship between working capital supervision and DEVA.
H1a: There is a significant relationship between average collection period and DEVA.

$\mathrm{H} 1 \mathrm{~b}$ : There is a significant relationship between inventory turnover and DEVA.

The second main hypothesis $(\mathrm{H} 2)$ : There is a significant relationship between working capital supervision and market value added.

$\mathrm{H} 2 \mathrm{a}$ : There is a significant relationship between average collection period and market value added.

$\mathrm{H} 2 \mathrm{~b}$ : There is a significant relationship between inventory turnover and market value added.

\section{RESULTS}

Examining the Normal Distribution of Research Variables

Investigating the statistical assumptions is the early step in examining the research hypotheses. Testing the normality of the variables distribution is one of the prerequisites considered in the parametric tests of Pearson correlation coefficient and multivariate regression. Table 1 shows that after converting the data, the normality test has been carried out for the distribution of the scores. The significant level obtained in $\mathrm{K}-\mathrm{S}$ test for any of the six variables determined to be more than 0.05 . Therefore, it can be interpreted that the variables in the sample are normally distributed and the hypotheses might be tested through parametric tests.

\section{Examining the Normal Distribution of Research Variables}

Investigating the statistical assumptions is the early step in examining the research hypotheses. Testing the normality of the variables distribution is one of the prerequisites considered in the parametric tests of Pearson correlation coefficient and multivariate regression. Table 1 shows that after converting the data, the normality test has been carried out for the distribution of the scores. The significant level obtained in $\mathrm{K}-\mathrm{S}$ test for any of the six variables determined to be more than 0.05 . Therefore, it can be interpreted that the variables in the sample are normally distributed and the hypotheses might be tested through parametric tests.

Table-1: Normality Test of the Variables Distribution

\begin{tabular}{|c|c|c|}
\hline Variable & Kolmogorov & Significant \\
\hline Average collection period & 1.04 & 0.23 \\
\hline Inventory turnover & 0.88 & 0.55 \\
\hline Average payment period & 1.19 & 0.11 \\
\hline Cash conversion cycle & 1.09 & 0.18 \\
\hline DEVA & 0.69 & 0.71 \\
\hline MVA & 0.77 & 0.58 \\
\hline
\end{tabular}


Testing the First main Hypothesis

The first main hypothesis: There is a $\mathrm{H} 0: \rho=0$ significant relationship between working capital H1: $\rho \neq 0$ management and DEVA.

Multivariate regression is used to test this hypothesis according to the specific characteristics of the collected data. The statistical description of this hypothesis is as follows:

In the above hypothesis, $\rho$ is the regression coefficient between the elements of working capital supervision and DEVA.

Table-2: Findings of the regression coefficient for predicting DEVA through the elements of working capital supervision:

\begin{tabular}{|l|l|l|l|l|}
\hline \multicolumn{1}{|c|}{ Variables } & R & R2 & Adjusted R2 & (P) \\
\hline $\begin{array}{l}\text { DEVA- elements of } \\
\text { working capital } \\
\text { management }\end{array}$ & 0.09 & 0.008 & 0.001 & 0.41 \\
\hline
\end{tabular}

As shown above, by using the multivariate regression coefficient, the linear significant relationship be-tween DEVA and elements of working capital management doesn't exist. Additionally, the independent variables of working capital supervision can merely predict 80 percent of the variations in the dependent variable. The significant level is also computed to be 0.41 which is higher than the intended significance level of 0.05 and it confirms that there is no significant linear relationship between these variables. The regression analyses are provided about the independent variables.

Table-3: Results of analyzing the regression of coefficients of any of the independent variables in the first main hypothesis

\begin{tabular}{|c|c|c|c|c|c|c|}
\hline \multicolumn{7}{|c|}{ a + Cash Conversion Cycle $3+\beta$ Inventory Turnover $3+\beta$ Payment Period $+\beta 2$ Collection Period $=\beta 1$ DEVA } \\
\hline Explanatory Variable & $\mathrm{B}$ & $\mathrm{SE}_{\mathrm{b}}$ & Beta & t-statistic & p-value & VIF \\
\hline Residual value & $83067 / 29$ & 106516.14 & & 0.78 & 0.43 & \\
\hline Average collection period & -448.65 & 952.30 & -0.040 & -0.471 & 0.638 & 0.415 \\
\hline Average payment period & -557.19 & 628.78 & -0.066 & -0.886 & 0.37 & 0.522 \\
\hline Cash conversion cycle & 180.83 & 529.85 & 0.032 & 0.34 & 0.73 & 0.34 \\
\hline Inventory turnover & -8.15 & 325.22 & -0.012 & -0.20 & 0.86 & 0.85 \\
\hline $\mathrm{F}$ & \multicolumn{6}{|c|}{0.916} \\
\hline p-value & \multicolumn{6}{|c|}{0.434} \\
\hline Durbin-Watson & \multicolumn{6}{|c|}{1.75} \\
\hline
\end{tabular}

The above mentioned findings related to VIF index and Durbon-Watson statistics represent that the assumption of nonlinearity of the independent variables is confirmed. As shown in table 3, $\mathrm{t}$ statistics of the working capital management are not significant at the level of 0.05 . This is because the significance levels of any of the working capital management variables are greater than the intended level of 0.05 . Additionally, $f$ statistics is 0.916 and $\mathrm{P}$-value is 0.434 which rejects the significance of these statistics at the level of 0.05 . Therefore, the significant relationship between working capital elements and DEVA is rejected and $\mathrm{HO}$ is then confirmed.
H1a: There is a significant relationship between average collection period and DEVA.

Pearson correlation coefficient is used to test this hypothesis according to the specific characteristics of the collected data. The statistical description of this hypothesis is as follows:

H0: $\rho=0$

$\mathrm{H} 1: \rho \neq 0$

In the above hypothesis, $\rho$ is the correlation coefficient between the average collection period and DEVA. 
Table-4: Results of testing the correlation in the relationship between average collection period and DEVA

\begin{tabular}{|l|l|l|l|}
\hline \multicolumn{1}{|c|}{ Variables } & $\mathrm{R}$ & $\mathrm{R} 2$ & $(\mathrm{P})$ \\
\hline $\begin{array}{l}\text { Average collection period } \\
\text { DEVA }\end{array}$ & -0.071 & 0.005 & 0.185 \\
\hline
\end{tabular}

Table 4 indicates that by using Pearson correlation coefficient, the linear relationship between the average collection period and DEVA is not confirmed. Additionally, the independent variable can predict 50 percent of the changes in the dependent variables of DEVA. This is because the significance level $(0.185)$ is more than the intended level of 0.05 . Consequently, the first subsidiary hypothesis is rejected and $\mathrm{HO}$ is confirmed.

H1b: There is a significant relationship between inventory turnover and DEVA.
The same as the prior subsidiary hypothesis, Pearson correlation coefficient is used to test this hypothesis according to the specific characteristics of the collected data. The statistical description of this hypothesis is as follows:

H0: $\rho=0$

$\mathrm{H} 1: \rho \neq 0$

In this hypothesis, $\rho$ is defined as the correlation coefficient between the inventory turnover and DEVA.

Table-5: Results of testing the correlation in the relationship between inventory turnover and DEVA

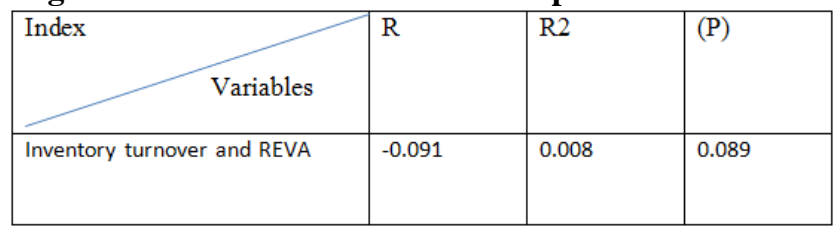

Applying Pearson correlation coefficient in the above hypothesis, the significant linear relationship between the two variables of inventory turnover and REVA is not confirmed. According to the above table, the independent variable of inventory turnover only predicts 80 percent of the variations in the dependent variable of DEVA. Based on the analyses, this hypothesis is rejected and $\mathrm{H} 0$ is confirmed.

\section{RESULTS OF THE SECOND MAIN HYPOTHESIS}

The second main hypothesis $(\mathrm{H} 2)$ : There is a significant relationship between working capital supervision and market value added.
In order to test this hypothesis, multivariate regression is performed according to the specific characteristics of the collected data. The statistical description of this hypothesis is as follows:

$\mathrm{H} 0: \rho=0$

$\mathrm{H} 1: \rho \neq 0$

In this hypothesis, $\rho$ is the regression coefficient between the elements of working capital supervision and market value added.

Table-6: Results of multivariate regression coefficient for predicting MVA by the elements of working capital supervision

\begin{tabular}{|l|l|l|l|}
\hline \multicolumn{1}{|c|}{ Index } & Rariable & R2 & $(\mathrm{P})$ \\
\hline $\begin{array}{l}\text { MVA and working capital } \\
\text { elements }\end{array}$ & 0.25 & 0.062 & 0.054 \\
\hline
\end{tabular}

Consistent with the prior hypotheses, by using the multivariate regression coefficient, the linear significant relationship between MVA and elements of working capital supervision is confirmed. Furthermore, the independent variable of working capital supervision predicts 6.20 percent of the variations in the dependent variable of MVA. Considering the above findings, it can be concluded that the variables are significantly associated. The regression analyses about the independent variables are examined in the following section. 
Michael Linus Ogbada et al., Sch Bull, Dec 2019; 5(12): 690-699

Table-7: Results of multivariate regression analyses for the coefficients of any of the independent variables

\begin{tabular}{|c|c|c|c|c|c|c|}
\hline Explanatory Variable & $\mathrm{B}$ & $\mathrm{SE}_{\mathrm{b}}$ & Beta & t-statistic & p-value & VIF \\
\hline Residual value & 154382.91 & 170883.29 & & 0.90 & 0.36 & \\
\hline Average collection period & -4831.98 & 1527.77 & -0.25 & -3.16 & 0.002 & 2.41 \\
\hline Average payment period & -4223.71 & 1008.75 & -0.304 & -4.18 & 0.0001 & 1.91 \\
\hline Cash conversion cycle & -1789.56 & 850.02 & -0.193 & -2.10 & 0.036 & 3.04 \\
\hline Inventory turnover & -9.96 & 325.22 & -0.023 & -1.13 & 0.25 & 2.85 \\
\hline $\mathrm{F}$ & \multicolumn{6}{|c|}{7.53} \\
\hline p-value & \multicolumn{6}{|c|}{0.0001} \\
\hline Durbin-Watson & & & .76 & & & \\
\hline
\end{tabular}

The findings related to VIF and DurbinWatson statistics verify the nonlinearity association between the independent variables. Table 9 documents that $t$ statistics of the average collection period, average payment period and cash conversion cycle are negatively significant. The significance level of any of the variables are less than 0.05 and 0.01 and F-statistics is equal to 7.53 and p-value of 0.0001 confirms that his is significant at a significance level less than 0.01 . Therefore, the second main hypothesis is confirmed and $\mathrm{HO}$ is rejected.
H2a: There is a significant relationship between average collection period and market value added.

According to the specific characteristics of the collected data, Pearson correlation coefficient is used to test the hypothesis. The statistical description of this hypothesis is as follows:

H0: $\rho=0$

$\mathrm{H} 1: \rho \neq 0$

In this hypothesis, $\rho$ is the correlation coefficient between average collection period and market value added.

Table-8: Results of the correlation test for the relationship between average collection period and MVA

\begin{tabular}{|l|l|l|l|}
\hline \multicolumn{1}{|c|}{ Index } & $\mathrm{R}$ & $\mathrm{R} 2$ & $(\mathrm{P})$ \\
\hline $\begin{array}{l}\text { Average collection period } \\
\text { and MVA }\end{array}$ & -0.182 & 0.033 & 0.001 \\
\hline
\end{tabular}

The findings disclosed in the table above confirm that there is a significant linear relationship between the two variables of average collection period and MVA in a negative form with the value of -0.182 . Addition-ally, the results reveal that the independent variable of average collection period predicts 3.30 percent of the variations in the dependent variable of MVA. Taking the significance level of 0.01 into account, it is concluded that this hypothesis is accepted and $\mathrm{H} 0$ is rejected.

$\mathrm{H} 2 \mathrm{~b}$ : There is a significant relationship between inventory turnover and market value added.
The specific characteristics of the collected data require performing Pearson correlation coefficient to test the hypothesis. The statistical description of this hypothesis is as follows:

$\mathrm{H} 0: \rho=0$

$\mathrm{H} 1: \rho \neq 0$

In this hypothesis, $\rho$ is the correlation coefficient between inventory turnover and market value added.

Table-9: Results of the correlation test for the relationship between inventory turnover and MVA

\begin{tabular}{|l|l|l|l|}
\hline \multicolumn{1}{|l|}{ Vndex } & $\mathrm{R}$ & $\mathrm{R} 2$ & $(\mathrm{P})$ \\
\hline $\begin{array}{l}\text { Inventory turnover and } \\
\text { MVA }\end{array}$ & -0.103 & 0.010 & 0.055 \\
\hline
\end{tabular}


Table 9. Shows that there is no significant linear relationship between the two variables of inventory turnover and MVA. Moreover, it is found that the inventory turnover predicts only 1.00 percent of the variations in the dependent variable of MVA. The obtained significance level is greater than the intended significance level (0.05) and it is an indicator that this hypothesis is rejected and $\mathrm{H} 0$ is confirmed.

\section{DISCUSSION, CONCLUSION AND SUGGESTIONS}

Working capital dealing with the current assets and liabilities has gained significant attention in the challenging economic environment of today. The optimal supervision of the working capital might impact the performance of the firms and considered as a competitive advantage. Working capital is the sum of the amounts invested in the current assets and working capital supervision is concerned with determining the volume and compound of the resources so that the shareholders' wealth is maximized. There are numerous prior studies conventionally concentrated on the longterm finance decisions and the researchers have also analyzed the issues related to investment, capital structure, and dividend and organization assessment. However, it should be noted that the major items of balance sheet include the investments on the short-term assets and those resources matured earlier than one year. Considering the challenging economic environment, the international organizations look for new ways for enhancing their growth and performance. They are also trying to mitigate the involved risk. Working capital is a significant resource for improving performance. The main objective of this study is to examine the effect of working capital supervision on the firms' performance. Distinguished market value added and market value added have been used to evaluate the performance. Consequently, a sample composed of 50 listed firms on the Nigerian Stock Exchange for a five year period covering 2013 to 2018 has been selected.

Using the regression and correlation analyses to test the hypotheses, the findings show that there is no significant relationship between the elements of working capital supervision and DEVA. The results of the statistical tests represent that there is no linear significant relationship between DEVA and the elements of working capital supervision at the level of 0.09. In addition, it was found that the independent variables merely predict 0.80 percent of the variations in the dependent variable. Furthermore, given the significant level (041) which is greater than the intended level (0.05), it can be concluded that these variables are not significantly associated. On the other hand, the findings related to test the four subsidiary hypotheses reveal that the average collection period, cash conversion cycle and inventory turnover are not significantly related. However, the results confirmed the negative significant relationship between average payment period and DEVA. That is, the firms can decrease the payment period to improve the performance of the shareholders. This requires the satisfactory management of the payments and application of the credit status of the creditors. Based on the statistical tests and regression and correlation analyses, it is found that the elements of working capital supervision and MVA are significantly associated. The other findings imply that MVA and the elements of working capital supervision are related at the level of 0.25 . The independent variables, moreover, predict 6.20 percent of the variations in the dependent variable of MVA. Finally, the results of the four subsidiary hypotheses of the second main hypothesis revealed that average collection period, average payment period and cash conversion cycle are negatively associated with MVA. However, inventory turnover and MVA are not significantly related.

The following suggestions are provided for the further discussions. In addition, numerous questions arise about the working capital supervision and elements of financial performance measures. These questions might be regarded as the schemes for the future studies:

- The sample of this study is a limited sample. Future studies might extend the sample to achieve more comprehensive findings. Implementing the policies related to the privatization of the firms and listing more firms on the Nigeria Stock Exchange provide the chance to increase the number of the firms as the sample.

- The time period of this study might be also extended. Future studies can be conducted in a longer time period.

- The further studies might be concentrated on the reasons for the lack of attention paid to the working capital supervision of the Nigeria listed firms.

\section{REFERENCES}

1. Ghahderijani, M. (2006). Examining the working capital policies in the automobile listed firms on the Tehran Stock Exchange during 1998 to 2004 (Doctoral dissertation, Master Thesis on Accounting, Shahid Bahonar University of Kerman).

2. Mohammadi, M. (2006). "The relationship between working capital management and its compo-nents with the firms' profitability", Master Thesis on Accounting, Mashhad Azad University.

3. Rahnema Roud Poshti, F., \& Kiyayi, A. (2009). "Describing the strategies of working capital management on the Tehran listed firms", Accounting Knowledge and Research, Fourth Year, 13, 1-13.

4. Enayati, S. (2004). "Explaining the current position of working capital management on the Tehran listed firms", Master Thesis on Accounting, Shahid Beheshti University. 
5. Khorram, Nezhad, M. (2007). “Operational examination of working capital management and the ef-fective factors", Master thesis of accounting, Ferdous University of Mashhad.

6. Ahmadabadi, M. R., Mehrabi, E., \& Yazdi, A. F. (2013). Impact of Working Capital Management on the Performance of the Firms Listed on the Tehran Stock Exchange. International Journal of Academic Research in Accounting, Finance and Management Sciences, 3(3), 352-364.

7. Izadi Niya, N., \& Taaki, A. (2010). Examining the impact of working capital management on the profitability of the Tehran listed firms. Financial Accounting Journal, 2th year, 5, 120-139.

8. Yaghoub Nezhad, A., Vakili Fard, H., \& Babayi, A. (2010). "The relationship between working capital management and profitability of the Tehran listed firms", Financial engineering and Portfolio management, 2, 117-137.

9. Assar Zadeh, H. (2011). "Impact of working capital management on the performance of the firms", Master Thesis on Accounting, Yazd Islamic Azad University.

10. Fathi, S., \& Tavakolli, Y. (2009). “The relationship between working capital management and financial operation of the economic entities", Journal of Business Reviews, No 36, pp 104-116.ehran listed firms", Master Thesis on Accounting, Shahid Beheshti University.

11. Reza Zadeh, J., \& Heydarian, J. (2010). "Impact of working capital management on the profitability of the Iranian firms" Financial Researches Quarterly, $1-20$.

12. Anand, M., \& Gupta, C. P. (2002). Working capital performance of corporate India: an empirical survey for the year 2000-2001. Management and Accounting research, January-June.

13. Howorth, C., \& Westhead, P. (2003). The focus of working capital management in UK small firms. Management Accounting Research, 14(2), 94-111.

14. Hosseini Azan Akhari, M. (2006). "The Relationship between REVA and EPS and P/E ratio", Thesis on Master of Accounting, Shiraz University.

15. Hanlon, M., Kelley Laplante, S., \& Shevlin, T. (2005). Evidence for the possible information loss of conforming book income and taxable income. The Journal of Law and Economics, 48(2), 407-442.

16. Padachi, K. (2006). Trends in working capital management and its impact on firms' performance: an analysis of Mauritian small manufacturing firms. International Review of business research papers, 2(2), 45-58.

17. Samiloglue, F. Demirnes, k. (2008)," The Effect Of Working Capital Management On Firm Profitability: Evidence From Turkey "The International Journal of Applied Economics and Finance. No. 1, Vol. 12. Fahimeh Nazari is a Master's degree student at Department of Management and Accounting, Islamic Azad University, Kermanshah Branch, Iran. Her research interests are working capital, Debt to Equity Ratio of Shareowners, Finance Management.

18. Atefat, M. (2010). "Examining the information content of tEVA and REVA for earnings prediction of Tehran listed firms", Master Thesis on Accounting, Marvdasht Islamic Azad University.

19. Nobanee, H., Abdullatif, M., \& AlHajjar, M. (2011). Cash conversion cycle and firm's performance of Japanese firms. Asian Review of Accounting, 19(2), 147-156.

20. Chion, C., Da Costa, L. E., \& Landry, J. A. (2006, July). Genetic programming for agricultural purposes. In Proceedings of the 8th annual conference on Genetic and evolutionary computation (pp. 783-790). ACM.

21. Skilling, J. S., Sood, A., Niemann, T., Lager, D. J., \& Buller, R. E. (1996). An abundance of p53 null mutations in ovarian carcinoma. Oncogene, 13(1), 117-123.

22. Heydar Pour, F., \& Mostofi, H. (2009). "The Relationship between Tobin's Q and REVA in Tehran listed firms", Financial Accounting Quarterly, (1), 20-37.

23. Stewart, G. B. (1999). The quest for value: a guide for senior managers.

24. Azarbayjani, K, Soroush, Yar, A., \& Yarian Koupayi, S. (2011). "Seeking for the best performance measure", Audit Journal, 52, 1-7. 